International Journal of Linguistics, Literature and Culture
Available online at https://sloap.org/journals/index.php/ijllc/
Vol. 6, No. 2, March 2020, pages: $67-76$
ISSN: 2455-8028
https://doi.org/10.21744/ijllc.v6n2.872

\title{
Function of Haroa Oral Tradition Practices in Religious Life towards Muna Society
}

\author{
Rahmat Sewa Suraya ${ }^{a}$ \\ A.A. Ngurah Anom Kumbara ${ }^{\text {b }}$ \\ Ida Bagus Gde Pujaastawa ${ }^{c}$ \\ Ni Made Wiasti ${ }^{\text {d }}$ \\ La Ode Topo Jers ${ }^{\mathrm{e}}$
}

\section{Article history:}

Submitted: 18 January 2019

Revised: 27 February 2020

Accepted: 09 March 2020

\section{Keywords:}

Haroa;

muna society;

Muslim;

oral tradition;

religious life;

\begin{abstract}
This paper aimed to observe the practice of Haroa oral traditions as a local culture related to the religious life of the Muna society. The Muna society was one of the ethnic groups in Southeast Sulawesi whose majority religion was Muslim. In the practice of religious life, the Muna society had oral tradition practices that had been passed down for generations, especially, those related to celebrating important days in the Islamic religion. In the current era, the Haroa oral tradition is still practiced by the Muna society although some society considers the tradition to be inappropriate even from certain Islamic groups, assuming tradition is very contrary to the teachings of the Islamic religion. A view assumes the practice of tradition is an act that is considered old-fashioned, upholding-is or heresy and so on. However, the Muna society who carry out the Haroa tradition considers the Haroa tradition has a very useful function for the society, especially, social life, cultural, and religious life.
\end{abstract}

International journal of linguistics, literature and culture (C) 2020.

This is an open access article under the CC BY-NC-ND license (https://creativecommons.org/licenses/by-nc-nd/4.0/).

\section{Corresponding author:}

Rahmat Sewa Suraya,

Halu Oleo University, Kendari, South East Sulawesi, Indonesia.

Email address: ijllc@sloap.org

\footnotetext{
${ }^{a}$ Halu Oleo University, Kendari, Indonesia

${ }^{\mathrm{b}}$ Udayana University, Denpasar, Indonesia

${ }^{c}$ Udayana University, Denpasar, Indonesia

${ }^{\mathrm{d}}$ Udayana University, Denpasar, Indonesia

${ }^{\mathrm{e}}$ Halu Oleo University, Kendari, Indonesia
} 


\section{Introduction}

The Muna society is one of the tribes inhabiting the Muna Island in Southeast Sulawesi Province. Like other tribes in Indonesia, the Muna tribe is very rich in oral traditions that are their characteristics and distinguish them from other tribes in Indonesia and even in the world (Couvreur, 2001). The diversity of oral traditions within the Muna tribe can be divided into four dimensions, as they are the oral traditions held by other tribes. The four dimensions as Dorson's (1963) opinion in Sukatman (2012) are 1) the dimension of orality, 2) the dimension of language, 3) the dimension of literacy, and 4) the dimension of cultural values.

One form of oral tradition in Muna society is still practiced up to current is an oral tradition deal with religious activities. The oral tradition in question is the Haroa oral tradition. Haroa oral tradition has long been carried out in Muna society. Even before the Muna society embraced Islam (Malik, 1997). After the entry of Islam, the Haroa oral tradition continues to be practiced in life even in religious activities unlike celebrating important days in Islam. Haroa oral tradition practices in the religious life of the Muna society are the celebration of the birthday of the Prophet Muhammad, SAW, the commemoration of Isra Mi'raj, the commemoration of Nifsu Sya'ban, the establishment of 1 (one) Ramadhan to initiate Ramadan Fasting, commemorating the coming of the Qur'an (Nuzul Qur'an), waiting for the night of Laitul Qadri, (waiting for Gabriel falling to earth), celebrating Eid, completing fasting after in the Ramadan month, and celebrating Eid al-Adha.

Some Haroa was carried out collectively by several family members. They were carried out by only one family head. Collective conduct is sometimes carried out in one house and other family members come to the house together to do the Haroa oral tradition. There is also Haroa in a mosque. All society members gather at one mosque while performing a Haroa. While Haroa is done by ahead of the family only at the house and followed by family members.

The implementation of the Haroa tradition has been challenged by many Islamic religious groups in Muna society, for example, Salafi group, Muhammadiyah, and other religious groups. These religious groups assume Haroa tradition is contrary to Islamic teachings. As it is stated in the Salafi propaganda jargon includes sanctions that, if someone takes other than Salafi in understanding Islam, it means that they have opposed the Prophet Muhammad and their end in the hell is the worst place to return. The society that follows the Salafi sect is a group of survivors. Due to they are on the path taken by the Prophet Muhammad and their friends (May, 2014).

Muna society continues to practice Harao tradition, especially, in celebrating important days in Islam. Many insults raised on the religious groups in their da'wah, unlike heresy, kafir, for those who practice the tradition, not to reduce the enthusiasm for the implementation of the tradition. For Muna society who practice the Haroa tradition, assume the tradition has a function for their lives both in social life and in religious life. For them, the tradition is not in conflict with religion, it even supports the spirit of diversity, especially in the practice of Islamic diversity (Rahmawati et al., 2018; Hills et al., 2005; Hoffman, 1997).

The purpose of this research is to enlighten the public, that the implementation of traditions has become a culture in a society that is not always in conflict with understanding or belief in religion, especially Islam. While the benefits to be gained are conceptually able to provide understanding and reinforcement to the society Haroa traditions and can be a reference material for further studies related to this topic.

\section{Literature Review}

Before getting to know more about how the Haroa oral tradition has a function in the religious life of the Muna society, it is better to review about the conception of tradition, oral tradition and the functions of a tradition.

\section{Concept of oral tradition}

Tradisi [tradition] (Latin: tradition, 'diteruskan' [passed on]) or habit, in the simplest sense, something has been done for a long time. It is part of the life of a social group, usually from a country, culture, time, or the same religion. The most basic thing from tradition is information that is passed on from generation to generation both written and oral because, without this, something can become extinct (Syarbini, 2011).

Oral tradition is "all discourse that is spoken includes the oral and the literate" or also stated as "a system of discourse that is not literate (Pudentia, 2015). Furthermore, oral tradition is explained that oral tradition is not only in the form of fairy tales, mythology, and legends with various messages in it but also about society's cognitive systems, sources of identity expression meaning, religion, and belief systems, the formation and reinforcement of 
customs, history, law, medicine, beauty, creativity, society origins, local wisdom in the society, and its environment. In this case, oral traditions are not only "oral traditions", but all cultural traditions passed down from one generation to another or later "from mouth to ear" using oral media (Sibarani, 2012).

Connecting some concepts above inspired the researchers to formulate the concept of the Haroa oral tradition is an oral tradition that is not literate. Haroa oral tradition is a cognitive system of society is related to the religious system as well as a system of social beliefs in long-standing religious diversity in society as a cultural phenomenon is passed down from one generation to another or later where the inheritance system is from mouth to ear with oral media (Swanson, 2008; Cashman \& Cronin, 2008; Minc, 1986; Phillips \& Hayes, 2008; Wehi et al., 2013).

\section{Oral tradition function}

An oral tradition or a tradition can still survive in a society because it has a function. The oral tradition function in general as the opinion of Danandjaja (2002), who also quoted from the opinion of the American oral tradition expert, Bacom (1984), that in general, the oral tradition has four important functions: 1) as projecting system (reflection) wishful thinking the collective idea, (2) as a means of legitimating cultural institutions, (3) functions as an educational tool, and (4) functions as a coercive or controlling tool. Therefore, social norms are always obeyed by their collective members.

Furthermore, to understand the function of an oral tradition/tradition can be studied using the theory of structural functionalism Merton (1975), as a student of Parson distinguishes the function nature to be two, namely: (1) manifest function and hidden function (latent). The terms provide important additions to functional analysis. In simple terms, a real function is an expected function while a hidden function is an unexpected function. Thinking can be related to Merton's concept, namely unanticipated consequences. Actions have consequences, expected and unexpected. Although everyone is aware of the expected effects, sociological analysis is needed to find these unintended consequences. Berger \& Luckmann (1963), called it a study "to dispel prejudice" (debuking) or to pay attention beyond real influence (Ritzer, 2014).

Understanding the function of Haroa oral traditions in Muna society using Merton structural functionalism, it can be understood the function can not only be understood from functions can be seen (manifest) as understood directly, but it can also be seen from functions that are not real (latent), meaning the function interpreted Muna society regarding Haroa tradition is not directly, but it must be interpreted after conducting a deeper study. Thus, a meaningful function is obtained in Muna society as a whole.

\section{Results and Discussions}

The basic concepts formation of cultural tradition and its development from generation to generation in traditional societies in the past were influenced by several factors. Two dominant factors are influencing, namely: (1) the belief factors and religious society beliefs; and (2) legalization factors of power and government (kingdom) systems. The factor of religious belief and belief adopted the society serves to instill the values and norms of sanctity or holiness of the concepts of teachings contained in the form of cultural traditions. The power legalizing factor of the royal government system in the past serves to instill the values and norms of coercive power to a form of cultural tradition. It functions as a reinforcement and bodyguard in the process of its development (correctional and civilizing).

The concept of historical and anthropological analytical thinking can be traced and formulated into the system of social life values in various regions in Indonesia. For example, the process of forming and developing Hindu and Buddhist cultural traditions for Java and Bali in the past. Of course, it is inseparable from the two factors role, namely the beliefs and religious beliefs of the society, which are then supported the power legalization from the Hindu-Buddhist government system. Likewise, after the influence of the teachings of Islam entered in Java and other regions in Indonesia. With a peaceful penetration system in its Islamic process, it always encourages the Islamic establishment empires, while also influencing the basic conception formation of its cultural traditions (Jafari \& Scott, 2014; Bonne \& Verbeke, 2008; Unkelbach et al., 2008). Due to the Islamic clerics played a role in forming royal rulers in formulating the basic concepts of culture at that time.

It starts from the above rationale to trace how the process of forming and developing the cultural traditions of the Muna society, whose values and norms, we still inherit to the day. Then, it is necessary to refer back to: (1) influence of Muna religious beliefs in the past; and (2) legalization of power from the Muna kingdom's government system at that time. Referring to the historical and anthropological analytical rationales, it turns out the forming process of basic concepts Muna cultural tradition, which appear in the forms of its mores to present:

Suraya, R. S., Kumbara, A. N. A., Pujaastawa, I. B. G., Wiasti, N. M., \& Jers, L. O. T. (2020). Function of Haroa oral tradition practices in religious life towards Muna society. International Journal of Linguistics,

Literature and Culture, 6(2), 67-76. https://doi.org/10.21744/ijllc.v6n2.872 
a) The basic concept of Muna culture was formed by the influence of religious understanding and the preIslamic Muna kingdom government system. In the cultural traditions form, it can be observed in the procedures for the implementation of katingka and kaago-ago and other animist understandings still influence the social system of Muna society to present.

b) The basic concept of the Muna cultural tradition formed by the compound results between the influence of pre-Islamic religion and Islamic teachings. Unlike, the custom of kaghombo (works), kagaa (marriage) and kasambu (bribes), as well as the concept of social stratification.

The basic concept of Muna cultural traditions formed by the influence of Islamic teachings. Unlike, the custom of kangkilo (katoba), patterns and ceremonies for certain months, according to the Hijriyah year calculation. For example, the commemoration of the birthday of the Prophet Muhammad in the early month of Rabiul, sending (reciting) al-Fatihah, al-Sincere, tahlil, and prayers to the spirits of parents and children of Muslim families who have died, every year in the month of Rajab. The commemoration of Nifsu Sa'ban in the month of Sa'ban, which is reading the Yasin letter three times and Nifsu Sa'ban prayers each time, to ask for long life, pure fortune, and strong faith, for the provision of worship to Allah SWT. It is also the commemoration of 1 Ramadhan, Eid al-Fitr and Eid al-Adha on 1 Shawwal and 10 Zulhijah and others (Malik, 1997). The detail about the implementation of the Haroa tradition in the diversity of the Muna society can be seen in Table 1.

Table 1

The Haroa oral tradition implementation in Muna religious diversity

\begin{tabular}{|c|c|c|c|}
\hline No. & $\begin{array}{l}\text { Timing of Haroa oral } \\
\text { tradition implementation }\end{array}$ & $\begin{array}{l}\text { Name of Haroa oral } \\
\text { tradition }\end{array}$ & Explanation \\
\hline 1. & $\begin{array}{l}12 \text { Early Rabiul- } 10 \\
\text { Final Rabbi }\end{array}$ & Haroa Maludhu & $\begin{array}{l}\text { Commemorating the Birthday of the Great Prophet } \\
\text { Muhammad, SAW. (Birthday of Prophet } \\
\text { Muhammad) }\end{array}$ \\
\hline 2. & 27 Rajab & Haroa Radjabu & Commemorating Isra Mi'raj \\
\hline 3. & 15 Sya'ban & Haroa Isyifu & $\begin{array}{l}\text { Commemorating the night of Nifsyu Sya'ban (as } \\
\text { another answer from the birth of Imam Mahdi) }\end{array}$ \\
\hline 4. & 1 Ramadhan & Haroa Tembahawula & $\begin{array}{l}\text { Determination of Ramadan } 1 \text { to start Ramadan } \\
\text { Fasting }\end{array}$ \\
\hline 5. & 17 Ramadhan & Haroa Qunu & $\begin{array}{l}\text { Commemorating the turmoil of the Qur'an (Nuzul } \\
\text { Qur'an) }\end{array}$ \\
\hline 6. & 21-27 Ramdhan & Haroa Qadhiri & $\begin{array}{l}\text { Waiting for the night of Laitul Qadri, (waiting for } \\
\text { Gabriel to fall to earth) }\end{array}$ \\
\hline 7. & 1 Shawwal & $\begin{array}{l}\text { Haroa Roreaha } \\
\text { Мри'u }\end{array}$ & Commemorating Eid al-Fitr \\
\hline 8. & 6 Shawwal & Haora Nomoalono & $\begin{array}{l}\text { Fulfill less fasting after fasting in the month of } \\
\text { Ramadan }\end{array}$ \\
\hline 9. & 10 Zulhidjah & $\begin{array}{l}\text { Haroa Roreaha } \\
\text { Hadji }\end{array}$ & Commemorating Eid al-Adha. \\
\hline
\end{tabular}

Table 1 shows a series of Haroa tradition implementation in a structured and sequential year. Their implementation is based on the local culture of the Muna society, having existed long before the Muna society converted to Islam. After the entry of Islam brought by the missionaries, the local culture had taken a basis in Muna society life was not immediately eliminated, but the local culture had taken a basis in Muna society was used as the Islamic religious broadcast media. Therefore, every celebration of important days in Islam is always included in the practice of the Haroa tradition. The Islam teachings brought by the missionaries can be well received. Therefore, the Haroa tradition practice currently is still carried out by the Muna society in celebrating important days in Islam diversity.

\subsection{Function of Haroa oral tradition practice in the religious life towards Muna society}

A tradition in every society can survive in social life, due to tradition has a function and useful in life. Danandjaja (2002), raised the opinion expert on American oral tradition, William R. Bascom, generally, the oral tradition 
functions as 1) as a system of projecting (reflecting) the collective imagination; 2) as a means of legitimating cultural institutions; 3) as an educational tool; 4) as a means of coercion or control, thus, the social norms are always obeyed by their collective members (Sukatman, 2012).

Merton (1975), stated measuring structurally society function look two functions existence exist in every social behavior in culture, namely (1) real function (manifest), and hidden function (latent). Real functions are expected functions and hidden functions are unexpected functions. The thinking can be related to Merton's other concepts, namely unanticipated consequences. Actions have expected and unexpected consequences. Although everyone is aware of the expected effects, sociological analysis is needed to find unexpected effects. Berger \& Luckmann (1963), called it a study "to dispel prejudice" (debuking) or to pay attention beyond real influence (Ritzer, 2014). Haroa oral tradition in the religious life in Muna society can be seen as a practice that has a function. The functions are as follows.

a) Haroa tradition as prayer momentum in the religious life of Muna society

Prayer as a means to ask/request to God strongly influence in the lives of every human being. It means acknowledging the human weaknesses and its dependence on God has become a blessing in itself. The Islam favors are present in the society have been integrated into Islamic tradition which later became its favor. Prayer's expressions to God can be done in the form of good character and devotion that is often done by society. If society believes in the power of prayer then that is the way to combine the demand for God and their endeavors for all social activities.

The commemorating major festival day tradition in Islam is always filled with "read" events that led to a villager. High priests are usually called by the title modhi kamokula, deputy high priests are usually called by the title modhi anahi. High priests and their deputies at special times they are usually tasked to lead worship in the old mosque [masigino wuna] relics of the Muna kingdom which became the district mosque. Modhino desa [village priest], Modhino hamlet [hamlet priest] or hatibi [khatib] play a role in villages that are appointed based on a direct appointment system of local society leaders and they act as a system of syara [religious council] in the society.

The commemorating tradition is an important day in the life of every family. Haroa tradition is food [commonly called haroa and cannot be compared to offerings] provided in bhosara which is usually coated with banana leaves before placing a variety of typical foods made by the host. Bhosara as an ordinary place of rice is always covered with a veil or cloth that must be white.

Haora's oral tradition usually priests will start with sentence questions:

\begin{tabular}{|l|l|}
\hline $\begin{array}{l}\text { daebhasagho ohae bhe ohaeno } \\
\text { sokamesalontomu nekakawasa }\end{array}$ & $\begin{array}{l}\text { "[we want to read what and what his/her request/our } \\
\text { intention to God" }\end{array}$ \\
\hline
\end{tabular}

the host then will answer:

daebasa daesalogho nekakawasa [nama hajat;
kaghosa, naolalesa radhakii, naewanta umuru,
dll]

[we read to ask for God's blessings such as strength, health, breadth of fortune, longevity, etc.]"

Imam then continues with the delivery from the host to the audience present with the sentence:

\begin{tabular}{|l|l|}
\hline $\begin{array}{l}\text { atumandamo aebhasa pada inia/abhasaemo } \\
\text { pada }\end{array}$ & [I will start reading/I read this] " \\
\hline
\end{tabular}

the present families and audiences then answered with the sentence:

"umbe 1 [ya]" [yes]"

The word "ya" as a sign everyone has understood and everyone present to submit their hearts and minds and focus on the readings of the Imam.

Suraya, R. S., Kumbara, A. N. A., Pujaastawa, I. B. G., Wiasti, N. M., \& Jers, L. O. T. (2020). Function of Haroa oral tradition practices in religious life towards Muna society. International Journal of Linguistics, Literature and Culture, 6(2), 67-76. https://doi.org/10.21744/ijllc.v6n2.872 
Imam after that will start with the reading of the Creed and seek forgiveness, then proceed with the recitation of the Qur'an which is usually the Surah Yasin then proceed with the reading of the prayer beads, tahmid, tahlil, and takbir are usually read 100 times each even up to 1,000 each time. It is continued by reading the prayer it is usually read the prayer refuse reinforcements and prayer the request of the desired grace or intention and prayer 'for families who have gone far away, families who are absent and for the spirits of families who have left the mortal world.' Then, the priest will touch the rice bowl and say a prayer so that the food will be a blessing for the family in the house. Then the closing of the prayer is to read the Surah Al Fatihah and continue with greetings with all those present at the event. One expression recited during greetings is as follows.

Dalumera ne lalo
Dalumera ne neati
Damokalalesa wubhano randa
Datuminda ne manusia bhainto
Naokesa ne fekiri
Naeta ne pogau
Siosiomo ompunobhada
Nafoseisegho welo imani
Be dhala metaano

Kabarakatino Omputo Laha Taala

Nando Nofowagho tora Kaghosa

Umuru Mewanta

Radhaki, sampe doratoe tora Roreaha

Taghu aini

Siosiomo Kakawasa

Nafowaghotora Umuru Mewanta

Darumatoe tora roreaha taghu tewise

Aesalo kaleramu wubano randanto gauku mpuu bari-barie nehalaghoku kamponano ini, bahi nomaigho nediuku, atawa newambaku, aitu aesaloane maafu, gauku mpu, kono korubu totono lalonto.

$:$ We are sincere in heart
$:$ We are sincere in intention
$:$ We open the heart
$:$ We are honest with others
$:$ Be kind
$:$ Good in words
$:$ Young God Almighty
$:$ Unite us in faith
$:$ And a good way

The prayer expression offered in Harao tradition can be seen as Haroa tradition moment is a way for the family or Muna society to become a unified society, a tradition of sharing and praying for one another. This is a part of local culture which is local wisdom which then adapts to Islamic traditions to show Islam is not in conflict with culture. The most important thing is the aim is only towards Allah (Abdullah et al., 2008). No matter how strong the reason for modern humans who sometimes come and blaspheme this tradition is the tradition of ignorance, heresy, infidelity, heresy, and all kinds of things will not be able to further examine what is contained in it if it has never pondered deeper.

b) Haroa tradition as conflict resolution media

The phenomenon of conflict anywhere can occur sometimes humans never expect or predict conflict will be present in the process of human interaction. Conflicts can occur without prior planning or guessing, as well as the consequences will result in human conflict cannot be expected. To avoid the conflict from causing undesired effects and can harm both property losses and lives. The conflict is immediately resolved. The steps to resolve the conflict occur are anticipated. Therefore, the conflict does not spread and cause bad consequences in social life. The conflict conditions are always present in the process of interaction that we can also find in social life. They are always present in the interaction process. We can also find it in Muna society. Their life in Muna society is always conflict and it is seen in their daily lives, with a sudden conflict can arise can damage the interaction process among the society, the conflict occurs both manifest (visible), or laten (invisible).

One effective way to resolve conflicts in Muna society is the Haroa tradition. There is a ritual celebrating important days in Islam. It is closely related to ceremonies or rituals to form a balance in the sense of creating the 
unity and truth of Islam in Muna society. According to Ibn Khalduln, true religion aims to create integration or social unity by controlling the provocative qualities in human beings such as envy and jealousy, even eliminating the rough and proud self-character. Religion exists during human life not to change local customs. Due to the customs are an inevitable aspect of the social situation, the society is located. Therefore, true religion solely seeks to eliminate civil war, regarding the social religious function, Affandi \& Khaldūn (2004), quoted Ibn Khaldun's thought which stated:

\begin{abstract}
"agama itu melenyapkan sifat kasar dan bangga diri, melatih untuk menguasai perasaan dengki dan cemburu. Apabila di kalangan mereka terdapat seorang nabi ataiu wali yang menyuruh mereka melaksanakan perintah Allah, melenyapkan sifat buruk yang mereka miliki, membuat mereka mengambil sifat terpuji, serta dapat menyatukan suara untuk menegakkan kebenara, maka mereka pun akan dapat berkumpul menjadi satu kesatuan sosial, dan memperoleh kemenangan (kekuasaan) serta kedaulatan".
\end{abstract}

Translation:

"Religion eliminates coarseness and pride, trains to master feelings of envy and jealousy. If among them there is a prophet or guardian who tells them to carry out God's commands, eliminate the bad qualities they have, make them take the praise quality and can unite the voice to uphold the truth, they then will be able to gather into one social entity and obtain victory (power) and sovereignty."

Following Ibn Khaldun's thought above, Haroa's oral tradition which is a ritual of celebrating important days in the Islamic religious life in Muna society apparently can increase intimacy between fellow citizens. Thus, they can connect the friendship broken up due to conflict. Haroa oral tradition begins with praying together, greetings, and continued with eating together can also be attended by invitations who are not only friends but also attended by the nearest neighbors or distant neighbors who come from different ethnicities. As it was stated by one informant.

\begin{abstract}
"kalau diadakan Haroa, yang datang ke rumah tidak sedikit, baik tetangga-tetangga yang dekat sini maupun tetangga-tetangga yang jauh. Mereka datang baik dipanggil maupun tidak, yang penting mereka dengar kalau akan diadakan Harao mereka langsung datang terutama ibu-ibunya mereka langsung datang dengan membawa ala kadarnya untuk keperluan baca-baca Haroa, kemudian saling bantu membantu memasak untuk keperluan baca-baca Haroa." (Interviewed, Wa Ode Hatima)
\end{abstract}

Translation:

"If it is held by Haroa, there are not a few coming to the house, both neighbors who are nearby and distant neighbors. They come either called or not, the most important thing is that they hear that Harao will be held, they come immediately, especially their mothers, they come immediately with rudimentary style for reading purposes Haroa, then helping each other to cook for the purposes of reading Haroa."

Muna Islamic society in conducting Haroa sometimes takes turns from house to house, especially Haroa Maludhu, Haroa Radjabu, Haroa Isyifu, and Haroa Nomoalono. The four Haroa are not all family heads in Muna society. The reason for the Haroa is not all family heads do it due to the cost considerations and reasons for habits that have been passed down from their parents. Wherein, if their parents have already done the Haroa, then their children still maintain to do the tradition and so on. Unlike the other Haroa, for example, Tembahawula, Qunu, Qadhiri, Roreaha Mpu'u, and Roreaha Hadji. Haroa every household implement it because it is a habit of every household in welcoming Ramadan month.

Like, Haroa Maludhu implementation, it was carried out in rotation even at the same time for about two weeks. A sense of togetherness and a sense of intimacy in the society is increasingly guaranteed because all the society in society visits each other without knowing the tribe as well as other haroa. Once the importance of implementation of Haroa oral traditions in the life of the Muna society. They are no longer think about the costs that must be spent on the needs of Haroa shopping needs. Whatever the costs incurred are not a burden on the mind, the important thing is their goal to celebrate every important moment in Islam diversity can be accomplished. They can gather both close and distant relatives and friends. The implementation of the Haroa tradition can create an atmosphere of intimacy,

Suraya, R. S., Kumbara, A. N. A., Pujaastawa, I. B. G., Wiasti, N. M., \& Jers, L. O. T. (2020). Function of Haroa oral tradition practices in religious life towards Muna society. International Journal of Linguistics, Literature and Culture, 6(2), 67-76. https://doi.org/10.21744/ijllc.v6n2.872 
harmony, and peace among fellow society members can create a harmonious atmosphere in the life of a nation and social state.

\section{Conclusion}

Based on the above discussion results, it can be concluded Haroa oral tradition is very functional in the religious life in Muna society. They are carried out not merely as ceremonial activities or mere ritual activities. However, the implementation of Haroa oral tradition, it has a very useful function for the religious life in a virtual society. Haroa oral tradition can be used as momentum in the religious activities in Muna society. Wherein Haroa oral tradition is not contrary to Islam teachings as alleged by sect groups or beliefs in Islam, but the oral tradition can increase the diversity spirit in Muna society, especially, Muna society which converted to Islam.

Haroa oral tradition can also integrate the society, so that, Haroa oral tradition is very appropriate as a moment for conflict resolution. It can add to the solidarity between fellow citizens and can do friendship who were cut off due to conflict. The function of Haroa oral tradition as momentum for prayer can be used as a moment to draw closer to God Almighty, as well as a moment to copy pray for the fellow family. Therefore, they are always in a stateprotected and get salvation from Almighty God. They have been rooted in Muna society culture should be retained in its implementation. Due to the tradition is not only profane oriented but also sacred oriented. Its implementation can be more quickly and easily accepted by society.

\section{Conflict of interest statement}

The authors declared that they have no competing interest.

\section{Statement of authorship}

The authors have a responsibility for the conception and design of the study. The authors have approved the final article.

\section{Acknowledgments}

With all humility, the authors express their deepest gratitude to all those who have contributed to the present paper. We express our gratitude especially to all informants who have provided a lot of information or data related to the research problems conducted. Southeast Sulawesi Province's research and development body that has given research permits to Muna Regency government, which has facilitated and provided various facilities in the context of conducting research. Similarly, thanks also to various parties who have helped in the completion of writing this paper. 


\section{References}

Abdullah, I., Mujib, I., \& Ahnaf, M. I. (2008). Agama dan kearifan lokal dalam tantangan global. Sekolah Pascasarjana UGM.

Affandi, H. I., \& Khaldūn, I. (2004). Akar konflik sepanjang zaman: elaborasi pemikiran Ibn Khaldun. Pustaka Pelajar.

Bacom, W. R. (1984). Four function of folklor. 1984). The study of folklore. Engelwood Clifis: NJ Pretice Hall.

Berger, P., \& Luckmann, T. (1963). Sociology of religion and sociology of knowledge. Sociology and Social Research, 47(4), 417-427.

Bonne, K., \& Verbeke, W. (2008). Muslim consumer trust in halal meat status and control in Belgium. Meat science, 79(1), 113-123. https://doi.org/10.1016/j.meatsci.2007.08.007

Cashman, K. V., \& Cronin, S. J. (2008). Welcoming a monster to the world: Myths, oral tradition, and modern societal response to volcanic disasters. Journal of Volcanology and Geothermal Research, 176(3), 407-418. https://doi.org/10.1016/j.jvolgeores.2008.01.040

Couvreur, J., \& Van Den Berg, R. (2001). Sejarah dan kebudayaan kerajaan Muna. Artha Wacana Press.

Danandjaja, J. (2002). Folklor Indonesia (Ilmu gosip, dongeng dan lain-lain Cet. VI. Jakarta: Pustaka Utama Grafiti.

Dorson, R. M. (1963). The American Folklore Scene, 1963. Folklore, 74(3), 433-449. https://doi.org/10.1080/0015587X.1963.9716918

Hills, P., Francis, L. J., \& Robbins, M. (2005). The development of the Revised Religious Life Inventory (RLI-R) by exploratory and confirmatory factor analysis. Personality and Individual Differences, 38(6), 1389-1399. https://doi.org/10.1016/j.paid.2004.09.006

Hoffman, V. J. (1997). The role of visions in contemporary Egyptian religious life. Religion, 27(1), 45-63. https://doi.org/10.1006/reli.1996.0051

Jafari, J., \& Scott, N. (2014). Muslim world and its tourisms. Annals of Tourism Research, 44, 1-19. https://doi.org/10.1016/j.annals.2013.08.011

Malik, L. M. (1997). Islam dalam Budaya Muna. Suatu Ikhtiar Menatap Masa Depan. Ujung Pandang: PT. Umitoha Ukhuwah Grafika.

May, A. (2014). Resistensi Aliran Salafi Terhadap Islam Tradisional Di Lombok Barat Nusa Tenggara Barat. Disertasi S3 Kajian Budaya, Unud, Denpasar.

Merton, R. K. (1975). Structural analysis in sociology.

Minc, L. D. (1986). Scarcity and survival: the role of oral tradition in mediating subsistence crises. Journal of Anthropological Archaeology, 5(1), 39-113. https://doi.org/10.1016/0278-4165(86)90010-3

Phillips, D. J., \& Hayes, B. A. (2008). Securing the oral tradition: Reflective positioning and professional conversations in midwifery education. Collegian, 15(3), 109-114. https://doi.org/10.1016/j.colegn.2007.09.002

Pudentia, M. P. S. S. (Ed.). (2015). Metodologi kajian tradisi lisan (edisi revisi). Yayasan Pustaka Obor Indonesia.

Rahmawati, N. N., Kumbara, A., \& Suda, I. K. (2018). Multiculturalism towards religious life in tewang tampang village: moral education implementation based local wisdom. International Journal of Linguistics, Literature and Culture, 4(6), 63-71. https://doi.org/10.21744/ijllc.v4n6.408

Ritzer, G. (2014). Edisi Ketujuh Teori Sosiologi Modern. Jakarta: Kencana Prenada Media Group.

Sibarani, R. (2012). Kearifan lokal: hakikat, peran, dan metode tradisi lisan. Asosiasi Tradisi Lisan (ATL).

Sukatman. (2012). Butir-Butir Tradisi Lisan Indonesia, Pengantar Teori dan Pembelajarnnya. Yogyakarta: LaksBang

Swanson, D. A. (2008). Hawaiian oral tradition describes 400 years of volcanic activity at Kîlauea. Journal of Volcanology and Geothermal Research, 176(3), 427-431. https://doi.org/10.1016/j.jvolgeores.2008.01.033

Syarbini, A. (2011, October). Islam dan Kearifan Lokal. Makalah yang dipresentasikan pada The 11 TH Annual conference On Islamic Studies. Bangka Belitung.

Unkelbach, C., Forgas, J. P., \& Denson, T. F. (2008). The turban effect: The influence of Muslim headgear and induced affect on aggressive responses in the shooter bias paradigm. Journal of Experimental Social Psychology, 44(5), 1409-1413. https://doi.org/10.1016/j.jesp.2008.04.003

Wehi, P., Cox, M., Roa, T., \& Whaanga, H. (2013). Marine resources in Māori oral tradition: He kai moana, he kai mā te hinengaro. Journal of Marine and Island Cultures, 2(2), 59-68. https://doi.org/10.1016/j.imic.2013.11.006

Suraya, R. S., Kumbara, A. N. A., Pujaastawa, I. B. G., Wiasti, N. M., \& Jers, L. O. T. (2020). Function of Haroa oral tradition practices in religious life towards Muna society. International Journal of Linguistics, Literature and Culture, 6(2), 67-76. https://doi.org/10.21744/ijllc.v6n2.872 


\section{Biography of Authors}

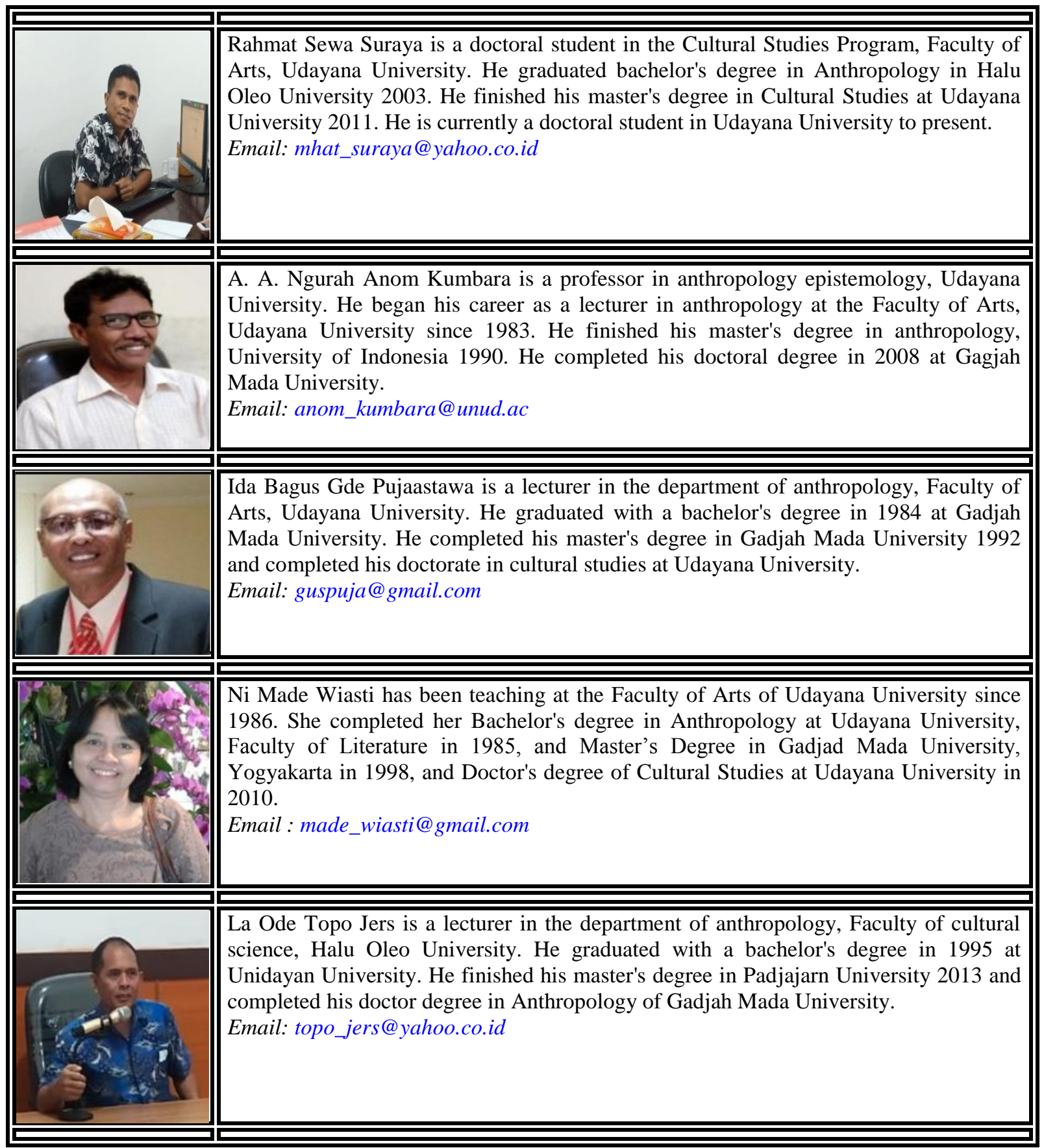

